\title{
Analisis Kemampuan Mahasiswa dalam Menerapkan Keterampilan Proses IPA dalam Pembelajaran pada Mata Kuliah Metodologi IPA MI
}

\section{Muhamad Afandi}

Prodi PGMI Fakultas Ilmu Tarbiyah dan Keguruan

Universitas Islam Negeri Raden Fatah Palembang

Email: muhammadafandi_uin@radenfatah.ac.id

\begin{abstract}
Abstrak
Penelitian ini bertujuan untuk mendeskripsikan: penerapan, kemampuan, dan permasalahan yang dialami mahasiswa PGMI dalam menerapkan pendekatan keterampilan proses IPA dalam praktik pembelajaran pada mata kuliah metodologi pembelajaran IPA MI. Metode penelitian ini menggunakan pendekatan kualitatif dengan jenis penelitian deskriptif atau disebut juga dengan penelitian deskriptif kualitatif. Teknik pengumpulan data menggunakan observasi, wawancara, dan dokumentasi. Pengecekan keabsahan data menggunakan ketekunan pengamatan, triangulasi, dan kecukupan referensial. Analisis data menggunakan persentase kemudian diolah melalui reduksi data, penyajian data, menarik kesimpulan dan verifikasi. Hasil penelitian ini antara lain: (1) Penerapan pendekatan keterampilan proses IPA dilaksanakan melalui langkahlangkah sebagai berikut: membagi mahasiswa ke dalam beberapa kelompok, menentukan dan mengembangkan materi pembelajaran IPA MI, mempersiapkan media atau alat peraga pembelajaran IPA MI, membuat perencanaan pembelajaran IPA MI, mengembangkan instrumen penilaian hasil pembelajaran IPA MI, dan menerapkan pendekatan keterampilan proses IPA (mengobservasi, memprediksi, mengklasifikasi, mengukur, menyimpulkan, dan mengkomunikasikan) dengan metode peer teaching; (2) Kemampuan mahasiswa PGMI dalam menerapkan pendekatan keterampilan proses IPA dalam pembelajaran pada mata kuliah metodologi IPA MI sudah baik; (3) Permasalahan yang dialami mahasiswa PGMI dalam menerapkan pendekatan keterampilan proses IPA antara lain: perencanaan pembelajaran yang kurang maksimal, mahasiswa masih kesulitan dalam mendesain pembelajaran, kurangnya media atau alat peraga, dan penguasaan materi yang kurang maksimal.
\end{abstract}

Kata kunci: Keterampilan proses, IPA, pembelajaran

\section{A. Pendahuluan}

Ilmu pengetahuan alam, sering disebut juga dengan istilah pendidikan sains, atau disingkat IPA. IPA merupakan salah satu mata pelajaran yang diajarkan pada pendidikan jenjang SD/MI. Mata pelajaran IPA selama ini dianggap sulit oleh sebagian besar siswa, mulai pada jenjang sekolah dasar sampai menengah. Anggapan sebagian besar siswa yang menyatakan bahwa IPA adalah mata pelajaran yang sulit adalah benar. Hal ini terbukti dari hasil perolehan Ujian Akhir Sekolah (UAS) yang dilaporkan oleh Depdiknas masih sangat jauh dari standar yang diharapkan. Ironisnya, justru semakin tinggi jenjang pendidikan, maka perolehan rata-rata nilai UAS pendidikan IPA ini menjadi semakin rendah (Susanto, 2016: 165).

Senada dengan hal tersebut, Wuryastuti (2008: 1) memaparkan beberapa permasalahan pembelajaran IPA yang terjadi di lapangan saat ini, antara lain: 
1. Proses belajar mengajar di sekolah belum memberikan kesempatan secara maksimal untuk mengembangkan kreatifitas siswa.

2. Bahan ajar yang digunakan masih kurang relevan dengan permasalahan pokok yang dihadapi masyarakat, terutama yang berkaitan dengan teknologi.

3. Pembelajaran IPA masih kurang dalam menekankan keterampilan proses.

4. Paradigma pelajaran IPA yang dilaksanakan masih bertujuan semata-mata untuk menyiapkan siswa melanjutkan pendidikan ke jenjang berikutnya.

IPA didefinisikan sebagai proses terpadu meliputi: perumusan masalah, penarikan kesimpulan dan sebagainya. Sementara itu, pembelajaran IPA menuntut siswa memiliki sikap ilmiah seperti jujur, teliti, cermat, mampu bekerja sama, dan sebagainya. Pembelajaran IPA sebagai produk memiliki komponen yang terdiri atas hukum dan teori (Panusu, 2010). Dari permasalahan pembelajaran IPA di atas hendaknya proses belajar mengajar IPA lebih menekankan pada keterampilan proses, sehingga pembelajaran berfokus pada siswa.

Berdasarkan hasil penelitian yang dilakukan oleh Yustami (Bakar, Halim, dan Mursal, 2015) tentang penerapan keterampilan proses sains terhadap pemahaman konsep siswa menunjukkan bahwa keterampilan proses sains dapat meningkatkan pemahaman konsep siswa. Demikian halnya dengan penelitian yang dilakukan oleh Kurniati juga menegaskan bahwa penerapan keterampilan proses sains dapat meningkatkan kemampuan berpikir kritis siswa. Dari hasil penelitian tersebut dapat dijelaskan bahwa penerapan keterampilan proses IPA dalam pembelajaran dapat digunakan untuk melatih kemampuan pemahaman dan daya berpikir kritis siswa. Untuk itu dalam hal ini Ulfa mendefinisikan keterampilan proses sebagai suatu pendekatan yang menekankan pada fakta dan konsep sebagaimana pendekatan atau kegiatan yang dilakukan oleh para ilmuwan dalam menguji atau membuktikan suatu teori yang kemudian diadopsi dalam pembelajaran IPA.

Lulusan Prodi PGMI FITK UIN Raden Fatah Palembang merupakan calon guru pada jenjang MI/SD, sehingga sangat penting untuk menguasai berbagai pendekatan dalam pembelajaran IPA, salah satunya adalah pendekatan keterampilan proses IPA. Berbagai pendekatan pembelajaran IPA dipelajari mahasiswa PGMI pada mata kuliah Metodologi Pembelajaran IPA MI. Dengan menguasai pendekatan keterampilan proses IPA ini diharapkan mahasiswa PGMI nantinya ketika menjadi guru mampu menciptakan pembelajaran IPA di MI/SD lebih bermakna, aktif, kreatif, dan menyenangkan. Untuk mengetahui sejauh mana kemampuan mahasiswa PGMI dalam menerapkan pendekatan keterampilan proses IPA dalam pembelajaran, maka perlu dilakukan suatu penelitian.

\section{B. Kajian Teori}

\section{Pengertian Keterampilan Proses IPA}

Pendekatan keterampilan proses merupakan pendekatan pembelajaran yang menekankan pada proses belajar, aktivitas dan kreativitas siswa dalam memperoleh pengetahuan, keterampilan, nilai dan sikap, serta menerapkannya dalam kehidupan sehari-hari. Dalam pengertian tersebut, termasuk diantaranya keterlibatan fisik, mental, 
dan sosial siswa dalam proses pembelajaran untuk mencapai suatu tujuan (Sugiyanto, 2009). Keterampilan proses adalah suatu pendekatan yang didasarkan pada langkahlangkah dalam menguji sesuatu hal yang biasa dilakukan oleh para ilmuwan pada waktu membangun atau membuktikan suatu teori (Nasution, dkk., 2008: 1.3). Keterampilan proses IPA merupakan keterampilan intelektual yang dimiliki dan digunakan oleh para ilmuwan dalam meneliti fenomena alam (Samatowa, 2016: 93).

Berdasarkan pengertian di atas dapat dirumuskan bahwa keterampilan proses IPA di MI adalah langkah-langkah yang digunakan ilmuwan untuk membangun dan membuktikan suatu teori yang diterapkan dalam pembelajaran IPA di MI. Keterampilan proses IPA yang digunakan para ilmuwan tersebut dapat dipelajari oleh siswa dalam bentuk yang lebih sederhana sesuai dengan tahap perkembangan siswa usia MI. Untuk mengajarkan keterampilan ini kepada siswa, maka siswa harus mempraktikkan kegiatankegiatan keterampilan proses tersebut ke dalam pembelajaran IPA. Untuk itu guru harus mampu mendesain pembelajaran IPA yang dapat mensimulasikan siswa menerapkan proses atau langkah-langkah yang dilakukan ilmuwan dalam menguji dan membuktikan suatu teori dalam pembelajaran.

\section{Jenis-jenis Keterampilan Proses Dasar IPA}

Funk (Trianto, 2013: 144) membagi keterampilan proses menjadi dua tingkatan, yaitu keterampilan proses tingkat dasar (basic science process skill) dan keterampilan proses terpadu (integrated science process skill). Keterampilan proses tingkat dasar meliputi: observasi, klasifikasi, komunikasi, pengukuran, prediksi, dan iferensi. Sedangkan keterampilan proses terpadu meliputi menentukan variabel, menyusun tabel data, menyusun grafik, memberi hubungan variabel, memproses data, menganalisis penyelidikan, menyusun hipotesis, menentukan variabel secara operasional, merencanakan penyelidikan, dan melakukan eksperimen. Pendekatan keterampilan proses yang dimaksud dalam penelitian ini adalah pendekatan keterampilan proses dasar IPA. Penentuan pendekatan keterampilan proses dasar didasari argumentasi bahwa pendekatan keterampilan proses dasar lebih relevan dengan tingkat kemampuan yang dimiliki siswa SD/MI.

Menurut Amin dkk. (Kumala, 2016: 10-11) keterampilan proses dasar terdiri dari: 1) Mengamati, mengamati diartikan sebagai proses menggunakan indera untuk mengamati objek dan kejadian, serta karakteristiknya (dalam bentuk catatan); 2) Mengklasifikasi, mengklasifikasi merupakan proses mengelompokkan objek-objek dan kejadian berdasarkan persamaan dan perbedaaanya (dalam bentuk daftar, tabel dan grafik); 3) Mengukur, mengukur adalah membandingkan kuantitas yang belum diketahui dengan standar (satuan panjang, waktu, suhu); 4) Menyimpulkan, menyimpulkan merupakan kegiatan membuat kesimpulan berdasarkan data-data hasil pengamatan; 5) Memprediksi, memprediksi merupakan sesuatu yang belum dibuktikan (bukan menebak) dengan keyakinan bahwa yang akan terjadi didasarkan pada pengetahuan dan pemahaman, pengamatan serta kesimpulan yang telah diperoleh; 6) Mengkomunikasikan, mengkomunikasikan dapat dituangkan secara lisan maupun tertulis dalam bentuk laporan, grafik, tabel dan gambar. 
Berdasarkan penejelasan dan pemaparan di atas, jenis-jenis pendekatan keterampilan proses IPA yang diteliti dalam penelitian ini yaitu: keterampilan mengobseravasi, keterampilan memprediksi, keterampilan mengklasifikasi, keterampilan mengukur, keterampilan menyimpulkan, dan keterampilan mengkomunikasikan.

\section{Langkah-langkah Keterampilan Proses IPA}

Langkah-langkah pelaksanaan pendekatan keterampilan proses adalah sebagai berikut (Suryosubroto, 2009):

a. Pendahuluan

Tujuan kegiatan ini adalah untuk mengarahkan siswa pada pokok permasalahan agar siswa siap, baik secara mental, emosional maupun fisik. Kegiatan ini antara lain dapat berupa: pengulasan langsung pengalaman yang pernah dialami siswa ataupun guru, pengulasan bahan pengajaran yang pernah dipelajarai pada waktu sebelumnya, kegiatan-kegiatan yang menggugah dan mengarahkan perhatian siswa antara lain meminta pendapat/saran siswa, menunjukkan gambar, slide, film, atau benda lain.

b. Kegiatan inti atau proses belajar mengajar

Proses belajar hendaknya selalu mengikutkan siswa secara aktif guna mengembangkan keterampilan-keterampilan proses, antara lain: mengamati, memprediksi, mengklasifikasi, mengukur, menyimpulkan, dan mengkomunikasikan.

c. Penutup

Pada kegiatan ini guru dapat melaksanakan refleksi dan evaluasi terhadap proseb belajar mengajar yang telah dilaksanakan. Pengembangan keterampilan proses itu memerlukan guru untuk bertanya dan menjawab pertnyaan siswa serta mengorganisasikan kelas. Untuk itu setiap guru secara mandiri dimintauntuk mengembangkan kemampuannya agar proses belajar mengajar yang mengembangkan keterampilan proses itu dapat berhasil.

\section{Metode Penelitian}

Penelitian ini menggunakan pendekatan kualitatif dengan jenis penelitian deskriptif atau disebut juga dengan penelitian deskriptif kualitatif. Teknik pengumpulan data yang digunakan dalam penelitian ini antara lain: observasi, wawancara, dan dokumentasi. Dalam penelitian ini, untuk menguji keabsahan data menggunakan teknik: ketekunan pengamatan, triangulasi, dan kecukupan referensial. Teknik analisis data yang digunakan adalah dengan teknik persentase kemudian dianalisis secara deskriptif kualitatif. Adapun langkah-langkah analisis data deskriptif kualitatif, yaitu: reduksi data, penyajian data, menarik kesimpulan dan verifikasi data.

\section{Hasil Penelitian dan Pembahasan}

\section{Hasil Penelitian}

a. Penerapan pendekatan keterampilan proses IPA pada mata kuliah metodologi IPA MI

Berdasarkan penelitian yang telah dilakukan, penerapan pendekatan keterampilan proses IPA pada mata kuliah metodologi IPA MI yang dilakukan oleh mahasiswa PGMI dilakukan dengan langkah-langkah sebagai berikut: 
1) Membagi mahasiswa ke dalam beberapa kelompok

2) Mahasiswa menentukan dan mengembangkan materi pembelajaran IPA MI

3) Mahasiswa mempersiapkan media atau alat peraga pembelajaran IPA MI

4) Membuat perencanaan pembelajaran IPA MI

5) Mahasiswa mengembangkan instrumen penilaian hasil pembelajaran IPA MI

6) Mahasiswa menerapkan pendekatan keterampilan proses IPA pada pembelajaran mata kuliah motodologi IPA MI

Penerapan pendekatan keterampilan proses IPA pada pembelajaran mata kuliah motodologi IPA MI ini dilakukan secara kelompok. Sedangkan metode praktikum mengajarnya menggunakan metode peer teaching. Metode pembelajaran peer teaching adalah metode pembelajaran rekan sebaya atau metode yang menuntut peserta didik untuk mampu mengajar peserta didik lainnya. Jadi dalam penerapan pendekatan keterampilan proses IPA pada pembelajaran mata kuliah motodologi IPA MI ini ada mahasiswa yang berperan sebagai guru dan ada mahasiswa yang berperan sebagai peserta didik.

Langkah-langkah penerapan pendekatan keterampilan proses IPA yang dilaksanakan mahasiswa dalam pembelajaran dapat dijelaskan sebagai berikut:

1) Mengobservasi

Peserta didik menggunakan segenap panca indera yang dimiliki untuk merumuskan dan mengidentifikasi masalah guna memperoleh informasi dan data mengenai benda atau peristiwa.

2) Memprediksi

Peserta didik menyatakan dugaan beberapa kejadian yang akan datang atas dasar data dan informasi yang diperoleh.

3) Mengklasifikasi

Peserta didik mengkategorikan suatu objek berdasarkan sifat-sifat atau karakteristik objek tersebut.

4) Mengukur

Peserta didik membandingkan suatu besaran dengan besaran lain yang digunakan sebagai patokan, baik dengan standar baku ataupun yang tidak baku.

5) Menyimpulkan

Peserta didik membuat pernyataan tentang pendapatnya berdasarkan fakta yang diperoleh.

6) Mengkomunikasikan

Peserta didik menyampaikan hasil pengamatan dan penelitiannya kepada orang lain.

b. Analisis kemampuan mahasiswa PGMI dalam menerapkan pendekatan keterampilan proses IPA dalam pembelajaran pada mata kuliah metodologi IPA MI

Berdasarkan data rekapitulasi kelompok yang menerapkan keterampilan proses pada pembelajaran mata kuliah metodologi IPA diketahui bahwa kelompok I mendapatkan rata-rata 66\% dengan predikat kurang. Kelompok II mendapatkan rata-rata 96\% dengan predikat sangat baik. Selanjutnya kelompok III mendapatkan rata-rata 93\% 
dengan predikat sangat baik. Untuk kelompok IV mendapatkan rata-rata 83\% dengan predikat baik. Begitu juga dengan kelompok V rata-rata yang diproleh adalah 86 dengan predikat baik. Sedangkan untuk kelompok VI mendapatkan rata-rata $96 \%$ dengan predikat sangat baik. Dari semua data tersebut dapat dijelaskan bahwa kelompok II dan kelompok VI memperoleh rata-rata tertinggi, sedangkan rata-rata terendah diperoleh kelompok I.

Dari seluruh data penerapan keterampilan proses pada pembelajaran mata kuliah metodologi IPA MI dapat diketahui bahwa keterampilan proses mengobservasi mendapatkan jumlah skor 28 dan keterampilan proses memprediksi jumlah skornya 24 . Untuk keterampilan proses mengklasifikasi dan mengukur mendapatkan jumlah skor yang sama yaitu 26. Sedangkan keterampilan proses mengukur mendapatkan jumlah skor 25 dan keterampilan proses mengkomunikasikan mendapatkan skor 28. Dari keseluruhan jenis keterampilan proses IPA yang diterapkan secara klasikal diperoleh jumlah 157 dengan persentase rata-rata sebesar $87 \%$. Berdasarkan analisis data ini maka dapat disimpulkan bahwa kemampuan mahasiswa PGMI dalam menerapkan pendekatan keterampilan proses IPA dalam pembelajaran pada mata kuliah metodologi IPA MI sudah baik.

\section{c. Kendala yang dialami mahasiswa PGMI dalam menerapkan pendekatan keterampilan proses IPA dalam pembelajaran pada mata kuliah metodologi IPA MI}

Berdasarkan hasil penelitian yang telah dilaksanakan, ditemukan beberapa kendala yang dialami beberapa mahasiswa dalam menerapkan pendekatan keterampilan proses IPA dalam pembelajaran pada mata kuliah metodologi IPA MI. Kendala-kendala tersebut antara lain:

1) Perencanaan pembelajaran yang kurang maksimal

Hal inilah yang dialami mahasiswa ketika menerapkan pendekatan keterampilan proses IPA dalam praktik pembelajaran. Beberapa mahasiswa mengalami kesulitan menerapkan langkah-langkah pendekatan keterampilan proses IPA karena penyusunan RPP kurang maksimal. Oleh karena itu sebelum mahasiswa praktik mengajar diwajibkan untuk membuat RPP terlebih dahulu. Dengan membuat RPP mahasiswa dapat merencanakan kegiatan apa saja yang akan dilaksanakan menyesuaikan dengan langkahlangkah pendekatan keterampilan proses IPA, menyiapkan materi, membuat media dan alat peraga, menyusun instrumen evaluasi yang akan digunakan dalam pembelajaran.

2) Mendesain pembelajaran dengan pendekatan keterampilan proses

Kendala berikutnya adalah kesulitan mahasiswa dalam mendesain pembelajaran dengan pendekatan keterampilan proses IPA. Mahasiswa masih kesulitan dalam menghubungkan materi pelajaran dengan langkah-langkah pendekatan keterampilan proses IPA. Beberapa mahasiswa masih belum memahami secara maksimal tentang pendekatan keterampilan proses IPA baik secara teoritis maupun praktis. Hal ini tentu saja berimplikasi pada proses pendesainan keterampilan proses IPA pada pembelajaran 
yang pada akhirnya juga akan berpengaruh pada proses penerapannya yang kurang maksimal.

3) Kurangnya media dan alat peraga

Mahasiswa mengalami kesulitan dalam mengontrol kelas dikarenakan media dan alat peraga pembelajaran yang digunakan kurang maksimal. Hal ini menyebabkan peserta didik kurang fokus perhatiannya dalam pembelajaran. Beberapa peserta didik ada yang sibuk belajar dan ada juga yang sibuk dengan aktivitasnya sendiri. Idealnya mahasiswa ketika membuat media atau alat peraga dapat membuat pertimbangan tentang berapa jumlah media dan alat peraga yang diperlukan, metode apa yang akan diterapkan dan siapa saja yang akan menggunakan media tersebut. Dengan pertimbangan ini penggunaan media dapat maksimal karena penerapan pendekatan keterampilan proses IPA sangat memerlukan media atau alat peraga.

4) Penguasaan materi yang kurang maksimal

Ada beberapa mahasiswa yang masih belum menguasai materi pelajaran yang disampaikan. Sehingga dalam praktiknya mahasiswa terkadang masih melihat buku ketika memberikan penjelasan materi. Hal ini bisa juga disebabkan karena mahasiswa belum terbiasa mengajar. Mahasiswa masih merasa kurang percaya diri ketika harus berdiri di depan kelas menjelaskan materi pelajaran kepada peserta didik. Seorang guru sebelum mengajar di kelas harus sudah menguasai materi pelajaran agar materi pelajaran tersebut tuntas tersampaikan dan juga tuntas dikuasai oleh peserta didik. Ketika guru tidak menguasai materi pelajaran pastinya juga peserta didik tidak akan mampu menguasai materi pelajaran tersebut secara maksimal. Mahasiswa harus sering belajar dan berlatih terus menerus sehingga kompetensi seorang guru akan terbentuk secara profesional.

\section{Pembahasan}

\section{a. Penerapan pendekatan keterampilan proses IPA pada mata kuliah metodologi IPA MI}

Febrianti (2014) menjelaskan bahwa metode pembelajaran peer teaching adalah suatu strategi pembelajaran yang kooperatif dimana rasa saling menghargai dan mengerti dibina di antara peserta didik yang bekerja bersama. Peer teaching ini memudahkan belajar, peserta didik berpartisipasi aktif, dan dapat memecahkan masalah bersama-sama, sehingga pemerataan pemahaman terhadap materi pembelajaran yang diberikan dapat tercapai. Metode pembelajaran peer teaching mempunyai beberapa manfaat, yaitu: 1) membagi mahasiswa menjadi beberapa kelompok kecil, 2) dengan melibatkan seluruh mahasiswa ke dalam belajar aktif, akan meredam perasaan cemas pada saat pelajaran dimulai, dan 3) mengeksplorasi materi yang dianggap sulit dan masih sangat asing bagi mahasiswa (Martono, 2008).

Senada sengan pendapat di atas, dengan metode yang digunakan ini sangat membantu mahasiswa dalam melaksanakan praktik mengajar. Mahasiswa terlihat lebih percaya diri dan tidak canggung karena mengajar rekan sendiri bukan orang baru atau orang yang belum mereka kenal. Suasana kelas menjadi kondusif karena mahasiswa dapat memerankan peran mereka masing-masing dengan baik. Mahasiswa yang berperan menjadi guru melaksanakan tugas mengajarnya dengan baik dan mahasiswa yang 
berperan menjadi peserta didik juga proaktif melaksanakan tugas dan arahan yang diberikan kepadanya.

Dari penerapan pendekatan keterampilan proses IPA dengan metode peer teaching ini perlu dipahami bahwa metode praktik mengajar ini tidak menghadirkan mahasiswa praktikum pada kondisi belajar yang sebenarnya karena peserta didik yang diajar adalah rekan sejawat bukan peserta didik SD/MI yang sebenarnya. Untuk itu ada beberapa catatan dari penerapan pendekatan keterampilan proses IPA dengan metode peer teaching yang telah dilaksanakan, antara lain:

1) Dari aspek guru, ada beberapa mahasiswa yang belum menjiwai perannya sebagai guru dalam praktik mengajar sehingga ketika mengajar baik dari cara menjelaskan, bahasa atau kalimat yang digunakan masih sama seperti ketika mahasiswa presentasi di perkuliahan. Hal yang demikian ini kurang tepat apabila diterapkan untuk mengajar peserta didik pada jenjang SD/MI. Untuk itu mahasiswa ketika praktik mengajar harus benar-benar menjiwai perannya sebagai guru sehingga dapat melaksanakan tugas dan peran sebagai guru SD/MI secara maksimal dalam mengajar di dalam kelas.

2) Dari aspek peserta didik, mahasiswa yang berperan sebagai peserta didik pada umumnya telah memiliki kompetensi jauh berada di atas kompetensi peserta didik SD/MI baik dari segi pengetahuan, sikap, dan keterampilan. Hal ini menyebabkan mahasiswa yang praktik mengajar sebagai guru terasa lebih mudah dan mengalir saja tidak menemukan kesulitan atau tantangan dalam mengajar dikarenakan peserta didik sudah memiliki kemampuan dalam memahami materi pelajaran yang diajarkan. Untuk itu perlu dilakukan usaha yang maksimal juga dari mahasiswa yang berperan sebagai peserta didik untuk mampu menjiwai dan berperan sesuai karakteristik peserta didik $\mathrm{SD} / \mathrm{MI}$.

3) Dari aspek proses pembelajaran, walaupun metode praktik mengajar ini tidak menghadirkan mahasiswa pada kondisi mengajar peserta didik SD/MI yang sebenarnya, esensi kegiatan pembelajaran ini terletak pada kemampuan mahasiswa dalam menciptakan atau mendesain pendekatan keterampilan proses IPA pada pembelajaran yang terlihat dari aktivitas belajar peserta didik dalam mengobservasi, memprediksi, mengklasifikasi, mengukur, menyimpulkan, dan mengkomunikasikan. Jadi dapat disimpulkan bahwa indikator keberhasilan penerapan pendekatan keterampilan proses dapat diukur dari langkah-langkah pendekatan keterampilan proses IPA yang tampak pada aktivitas belajar peserta didik.

b. Analisis kemampuan mahasiswa PGMI dalam menerapkan pendekatan keterampilan proses IPA dalam pembelajaran pada mata kuliah metodologi IPA MI

Analisis kemampuan mahasiswa PGMI dalam menerapkan pendekatan keterampilan proses IPA dalam pembelajaran pada mata kuliah metodologi IPA MI dianalisis dari indikator pendekatan keterampilan proses IPA yang dipraktikan mahasiswa dalam pembelajaran. Indikator pendekatan keterampilan proses IPA tersebut antara lain:

1) Keterampilan mengobservasi

JIP: Jurnal Ilmiah PGMI.

Volume 4, Nomor 2, Desember 2018

P-ISSN: 2527-4589

Available online at http://jurnal.radenfatah.ac.id/index.php/jip 
Menurut Trianto (2013: 144-145) kegiatan observasi dilakukan dengan penggunaan indera-indera yang ada, yaitu: dengan penglihatan, pendengaran, pengecapan, perabaan, dan pembauan. Beberapa perilaku yang dikerjakan peserta didik pada saat observasi, antara lain: penggunaan indera-indera tidak hanya penglihatan, pengorganisasian objek-objek menurut satu sifat tertentu, pengidentifikasian banyak sifat, melakukan pengamatan kuantitatif, melakukan pengamatan kualitatif

Sebagaimana pendapat di atas, berbeda dengan kelompok I, dalam kegiatan mengobservasi ini, kelompok II, III, IV, V, dan VI mampu melaksanakan kegiatan mengobservasi dalam pembelajaran dengan menggunakan panca indera peserta didik secara maksimal. Hal ini dikarenakan kelompok II sampai VI telah membuat dan mengembangkan media dan alat peraga pembelajaran sesuai dengan kebutuhan. Hal tersebut juga didukung dengan kemampuan mahasiswa dalam menggunakan media dan alat peraga dalam pembelajaran. Dari data yang diperoleh dari kegiatan mengobservasi dapat disimpulkan bahwa mahasiswa PGMI sudah sangat baik.

2) Memprediksi

Berdasarkan data hasil penelitian yang diperoleh, diketahui bahwa dalam menerapkan keterampilan memprediksi ini mahasiswa mendapatkan predikat cukup. Hal ini dikarenakan mahasiswa belum mampu secara maksimal mengoptimalkan peserta didik dalam kegiatan memprediksi. Beberapa peserta didik mengalami kebingungan dalam membuat prediksi. Padahal jika dilihat dari kegiatan observasi, peserta sudah baik. Penyebabnya adalah mahasiswa kurang mampu memberikan penjelasan dan menghubungkan data yang diperoleh peserta didik melalui observasi dengan kegiatan memprediksi sehingga peserta didik mengalami miskonsepsi.

Menurut Trianto (2013: 145) memprediksi merupakan pengajuan hasil-hasil yang mungkin dihasilkan dari suatu percobaan. Prediksi tersebut didasarkan pada data pengamatan-pengamatan yang diperoleh sebelumnya. Beberapa perilaku peserta didik dalam kegiatan memprediksi antara lain: penggunaan data dan pengamatan yang sesuai, penafsiran generalisasi tentang pola-pola, pengujian kebenaran dari ramlan-ramalan yang sesuai.

3) Keterampilan mengklasifikasi

Mengklasifikasi merupakan kegiatan mengelompokkan atau menggolongkan suatu obyek berdasarkan syarat-syarat tertentu. Proses mengklasifikasi tersebut dapat dilihat dari persamaan, perbedaan, ciri-ciri, sifat, membandingkan, dan dasar pengelompokan. Kegiatan mengklasifikasi ini sangat bermanfaat dalam melatih kecerdasan spasial peserta didik. Selaras dengan pendapat Trianto (2013: 145) pengklasifikasian adalah pengelompokkan objek-objek menurut sifat-sifat tertentu. Beberapa perilaku peserta didik dalam kegiatan pengklasifikasian ini antara lain: mengidentifikasian suatu sifat umum, memilah-milahkan dengan menggunakan dua sifat atau lebih

Dalam kegiatan mengklasifikasi ini, secara umum mahasiswa membentuk peserta didik ke dalam beberapa kelompok kemudian membagikan media atau alat peraga pembelajaran. Setelah itu mahasiswa meminta peserta didik untuk melakukan kegiatan 
mengklasifikasi. Kegiatan mengklasifikasi yang telah dilaksanakan mahasiswa dalam praktik mengajar antara lain: meminta peserta didik untuk mengelompokkan jenis-jenis wujud benda, organ-organ pernafasan, bagian-bagian tumbuhan, jenis-jenis daun, dan lainnya. Berdasarkan data hasil penelitian yang diperoleh dapat disimpulkan bahwa kemampuan mahasiswa PGMI dalam merapkan keterampilan mengklasifikasi ini sudah baik.

4) Keterampilan mengukur

Menurut Trianto (2013: 146) pengukuran adalah penemuan ukuran dari suatu objek, berapa massa suatu objek, berapa banyak ruang yang ditempati suatu objek. Objek tersebut dibandingkan dengan suatu pengukuran. Beberapa perilaku peserta didik dalam kegiatan pengukuran ini antara lain: pengukuran panjang, volume, massa, temperatur, dan waktu dalam satuan yang sesuai, memilih alat dan satuan yang sesuai untuk tugas pengukuran tertentu tersebut.

Berdasarkan data hasil penelitian yang diperoleh dapat disimpulkan bahwa kemampuan mahasiswa PGMI dalam menerapkan keterampilan mengukur sudah baik. Mahasiswa mampu melatih peserta didik untuk melaksanakan kegiatan pengukuran dengan alat ukur dan satuan tertentu terhadap media atau alat peraga pembelajaran yang telah disediakan mahasiswa.

5) Keterampilan menyimpulkan

Kegiatan menyimpulkan yang dilaksanakan mahasiswa dalam praktik mengajar antara lain: mahasiswa meminta peserta didik untuk menyampaikan pendapatnya tentang proses pernafasan manusia, menyimpulkan jenis daun beradasarkan bentuknya, perubahan wujud benda, sifat cahaya, pengaruh gaya dan bentuk benda. Berdasarkan data hasil penelitian yang diperoleh dapat disimpulkan bahwa kemampuan mahasiswa PGMI dalam menerapkan keterampilan menyimpulkan sudah baik. Mahasiswa mampu melatih peserta didik untuk membuat kesimpulan tentang konsep, fakta, dan prinsip yang telah dipelajari peserta didik.

6) Keterampilan mengkomunikasikan

Menurut Trianto (2013: 145-146) mengkomunikasikan adalah mengatakan apa yang diketahui dengan ucapan kata-kata, tulisan, gambar, demonstrasi, atau grafik. Beberapa perilaku yang dikerjakan peserta didiksaat melakukan komunikasi, antara lain: pemaparan pengamatan atau dengan menggunakan perbendaharaan kata yang sesuai, pengembangan grafik atau gambar untuk menyajikan pengamatan dan peragaan data, perancangan poster atau diagram untuk menyajikan data untuk meyakinkan orang lain.

Berdasarkan hasil penelitian yang diperoleh, dapat disimpulkan bahwa kemampuan mahasiswa PGMI dalam menerapkan keterampilan mengkomunikasikan sudah sangat baik. Mahasiswa selalu mengapresiasi pendapat yang disampaikan peserta didik, juga mampu memotivasi peserta didik sehingga peserta didik percaya diri dan berani untuk mengkomunikasikan pendapatnya.

\section{c. Kendala mahasiswa PGMI dalam menerapkan pendekatan keterampilan proses IPA dalam pembelajaran pada mata kuliah metodologi IPA MI}

1) Perencanaan pembelajaran yang kurang maksimal

JIP: Jurnal Ilmiah PGMI.

Volume 4, Nomor 2, Desember 2018

P-ISSN: 2527-4589

Available online at http://jurnal.radenfatah.ac.id/index.php/jip 
Dari hasil kajian secara teoritis, Sanjaya yang dikutip oleh Prastowo (2015) mengungkapkan bahwa manfaat perencanaan pembelajaran meliputi empat macam, yaitu: pertama, melalui proses perencanaan yang matang, kita akan mampu memprediksi seberapa besar keberhasilan yang akan dapat dicapai. Kedua, sebagai alat pemecah masalah. Keempat, untuk memanfaatkan berbagai sumber belajar secara tepat. Kelima, perencanaan akan dapat membuat pembelajaran berlangsung secara sistematis, artinya proses pembelajaran tidak akan berlangsung seadanya akan tetapi akan berlangsung secara terarah dan terorganisasi.

Seperti halnya apabila guru sukses dalam menerapkan pendekatan keterampilan proses dalam pembelajaran, peserta didik akan aktif dalam proses pembelajaran. Aktivitas belajar peserta didik tidak terbatas pada aktivitas fisiknya saja tetapi juga aktivitas mentalnya akan tereksplorasi. Pendekatan keterampilan proses ini sangat menekankan pada aktivitas proses pembelajaran yang akan mengembangkan kemampuan fisik dan mental peserta didik. Dengan mengembangkan keterampilan-keterampilan proses peserta didik akan mampu menemukan dan mengembangkan konsep, fakta, dan prinsip secara mandiri yang akan bermanfaat bagi peserta didik dalam mengembangkan pengetahuan, sikap, dan keterampilannya.

2) Mendesain pembelajaran dengan pendekatan keterampilan proses

Pendapat yang lebih spesifik dikemukakan oleh Gentry, yang berpendapat bahwa desain pembelajaran berkenaan dengan proses menentukan tujuan pembelajaran, strategi dan teknik untuk mencapai tujuan serta merancang media yang dapat digunakan untuk efektivitas pencapaian tujuan. Selanjutnya, Sanjaya (2015: 67) menambahkan bahwa untuk mendesain pembelajaran harus diawali dengan studi kebutuhan, sebab berkenaan dengan upaya untuk memecahkan persoalan yang berkaitan dengan proses pembelajaran siswa dalam mempelajari suatu bahan atau materi pembelajaran.

Masalah yang dialami oleh mahasiswa praktikum mengajar adalah kesulitan mahasiswa dalam mengaitkan langkah-langkah pendekatan keterampilan proses IPA dengan materi pelajaran dan penerapannya dalam pembelajaran. Jika dikaitkan dengan komponen-komponen belajar di atas, berarti permasalahan yang dihadapi mahasiswa adalah pada komponen materi pembelajaran dan pada komponen strategi pembelajaran. Untuk mengatasi permasalahan yang berkaitan dengan materi pembelajaran, yang harus dilakukan adalah memahami dan mempelajari jenis, ruang lingkup, urutan, dan perlakuan atau cara untuk mengajarkannya. Sedangkan untuk mengatasi permasalahan yang berkaitan strategi pembelajaran, mahasiswa harus mampu mengorganikan kelas terlebih dahulu agar tercipta iklim belajar yang kondusif. Berikutnya, mahasiswa harus memahami langkah-langkah keterampilan proses IPA secara detail terlebih dahulu sebelum menerapkannya dalam pembelajaran. Yang terakhir adalah mengaitkan materi pelajaran ke dalam keterampilan-keterampilan proses yang relevan.

3) Kurangnya media dan alat peraga

Sebagaimana hasil penelitian yang diperoleh menunjukkan bahwa ada beberapa mahasiswa yang mengalami kesulitan dalam menerapkan pendekatan keterampilan proses IPA karena media dan alat peraga yang digunakan jumlahnya kurang sehingga ada 
beberapa peserta didik yang harus menunggu giliran untuk menggunakan media dan alat peraga dalam melaksanakan aktivitas belajar keterampilan proses IPA. Berdasarkan penjelasan tersebut sebenarnya kesalahan mahasiswa terletak pada peroses analisis kebutuhan dalam mengembangkan media dan alat peraga. Kesalahan ini akhirnya berdampak pada proses pembelajaran dengan pendekatan keterampilan proses IPA yang kurang maksimal.

Sebagaimana yang dikemukakan oleh beberapa ahli ada beberapa kriteria yang dapat dilakukan dalam menetukan media pembelajaran atau alat peraga, antara lain (Sardiman, dkk., 2012):

a) Menurut Ely, pemilihan media seyogyanya tidak terlepas dari konteksnya bahwa media merupakan komponen dari sistem instruksional secara keseluruhan. Karen itu, meskipun tujuandan isinya sudah diketahui, faktor-faktor lain seperti karakteristik siswa, strategi belajar-mengajar, organisasi kelompok belajar, alokasi waktu dan sumber, serta prosedur penilaiannya juga perlu dipertimbangkan seperti: media apa saja yang ada, berapa harganya, berapa lama untu mendapatkannya, dan format apa yang memenuhi selera pemakai (siswa dan guru).

b) Dick dan Carey, selain kesesuaian dengan tujuan pembelajaran, setidaknya ada empat faktor yang perlu dipertimbangkan dalam pemilihan media, yaitu: pertama adalah ketersediaan sumber setempat; kedua adalah dana, tenaga, dan fasilitasnya; ketiga adalah keluwesan, kepraktisan, dan ketahanan media; keempat adalah efektivitas biayanya dalam jangka waktu yang panjang.

4) Penguasaan materi yang kurang maksimal

Berdasarkan hasil penelitian yang diperoleh, kendala yang dialami mahasiswa PGMI dalam menerapkan keterampilan proses IPA salah satunya adalah penguasaan materi pelajaran yang kurang maksimal. Untuk menjadi guru yang profesional, penguasaan materi pelajaran secara luas dan mendalam adalah mutlak dan wajib. Sebagaimana dijelaskan oleh Suryosubroto (2009: 4) kompetensi profesional merupakan profil kemampuan dasar yang harus dimiliki guru. Kompetensi tersebut akan mencerminkan fungsi dan peranan dalam membelajarkan anak didik. Kompetensi profesional guru perlu dikembangkan agar penguasaan akademis dapat terpadu secara serasi dengan kemampuan mengajar.

Untuk mengembangkan kemampuan mahasiswa dalam menguasai materi pembelajaran, sebelum mahasiswa mengajarkan materi pelajaran kepada peserta didik, mahasiswa harus mempelajari dan menguasai materi pelajaran tersebut terlebih dahulu. Jadi dapat disimpulkan bahwa pada hakikatnya dalam proses pembelajaran itu tidak hanya peserta didik saja yang diwajibkan untuk belajar, tetapi juga guru harus senantiasa belajar dan meningkatkan kompetensinya untuk menguasai dan mengajarkan materimateri pelajaran kepada peserta didik secara tuntas dan maksimal.

\section{E. Kesimpulan}

Berdasarkan hasil penelitian dan pembahasan yang telah dilaksanakan peneliti, kesimpulan penelitian ini adalah sebagai berikut:

JIP: Jurnal Ilmiah PGMI.

Volume 4, Nomor 2, Desember 2018

P-ISSN: 2527-4589

Available online at http://jurnal.radenfatah.ac.id/index.php/jip 
1. Penerapan pendekatan keterampilan proses IPA dalam praktik pembelajaran pada mata kuliah metodologi pembelajaran IPA MI dilaksanakan melalui langkah-langkah sebagai berikut: (a) membagi mahasiswa ke dalam beberapa kelompok; (b) menentukan dan mengembangkan materi pembelajaran IPA MI; (c) mempersiapkan media atau alat peraga pembelajaran IPA MI; (d) membuat perencanaan pembelajaran IPA MI; (e) mengembangkan instrumen penilaian hasil pembelajaran IPA MI; dan (f) menerapkan pendekatan keterampilan proses IPA dengan metode peer teaching: mengobservasi, memprediksi, mengklasifikasi, mengukur, menyimpulkan, dan mengkomunikasikan.

2. Kemampuan mahasiswa PGMI dalam menerapkan pendekatan keterampilan proses IPA dalam pembelajaran pada mata kuliah metodologi IPA MI sudah baik.

3. Permasalahan yang dialami mahasiswa PGMI dalam menerapkan pendekatan keterampilan proses IPA dalam praktik pembelajaran pada mata kuliah metodologi pembelajaran IPA MI antara lain: perencanaan pembelajaran yang kurang maksimal, mahasiswa masih kesulitan mendesain pembelajaran dengan pendekatan keterampilan proses, kurangnya media dan alat peraga, dan penguasaan materi yang kurang maksimal.

\section{F. Daftar Pustaka}

Abu Bakar. A. Halim. dan Mursal. 2015. Penerapan Pendekatan Ketrampilan Proses untuk Meningkatkan Ketrampilan Proses SAINS dan Penguasaan Konsep Siswa SMP pada Konsep Tekanan. Jurnal Pendidikan Sains Indonesia. Volume 3. Nomor 1.

Agus Sugiyanto. dkk,. 2009. Pembelajaran IPA MI. Surabaya. LAPIS-PGMI.

Ahmad Susanto. 2016. Teori Belajar dan Pembelajaran di Sekolah Dasar. Jakarta. Prenada Media Grup.

Andi Prastowo, 2015. Menyusun Rencana Pelaksanaan Pembelajaran (RPP) Tematik Terpadu: Implementasi Kurikulum 2013 untuk SD/MI. Jakarta. Prenadamedia Group.

B. Suryosubroto. 2009. Proses Belajar Mengajar di Sekolah. Jakarta. Rinekia Cipta.

Farida Nur Kumala. 2016. Pembelajaran IPA SD. Malang. Ediide Infografika.

Nanang Martono. Mintarti. Elis Puspitasari. 2008. Upaya Peningkatan Partisipasi Mahasiswa dalam Proses Pembelajaran Mata Kuliah Sosiologi Pendidikan Melalui Metode Peer Teaching dan Brainstorming. Jurnal Pendidikan dan Kebudayaan. Volume 14. Nomor 75.

Noehi Nasution. dkk.. 2008. Pendidikan IPA di SD. Jakarta. Universitas Terbuka.

Roestiyah N.K.. 2012. Strategi Belajar Mengajar. Rineka Cipta. Jakarta. 
Sardiman. dkk.. 2012. Media Pendidikan: Pengertian. Pengembangan. dan Pemanfaatannya. Jakarta. Rajawali Pers.

Sri Wuryastuti. April 2008. Inovasi Pembelajaran IPA di Sekolah Dasar. Jurnal Pendidikan Dasar. Nomor 9. .

Trianto. 2013. Model Pembelajaran Terpadu: Konsep. Strategi. dan Implementasinya dalam Kurikulum Tingkat Satuan Pendidikan (KTSP). Jakarta. Bumi Aksara.

Usman Samatowa. 2016. Pembelajaran IPA di Sekolah Dasar. Jakarta. Indeks.

Wina Sanjaya. 2015. Perencanaan dan Desain Sistem Pembelajaran. Jakarta. Prenadamedia Group.

Yopi Nisa Febianti. 2014. Peer Teaching (Tutor Sebaya) sebagai Metode Pembelajaran untuk Melatih Siswa Mengajar. Jurnal Edunomic. Volume 2. Nomor 2.

Yulin Dj. Panusu. 2010. Muhammad Jamhari. dan Amran Rede. Peningkatan Hasil Belajar Melalui Pendekatan Keterampilan Proses Pada Pembelajaran Perkembangbiakkan Pada Manusia di Kelas VI SDN Sansarino Kecamatan Ampana Kota. Jurnal Kreatif Tadulako. Volume 4. Nomor 4. 